European journal of American studies

\title{
It's Just a Jump to the Right: The Tea Party's Influence on Conservative Discourse
}

Richard D. Elliott

\section{(2) OpenEdition \\ Journals}

Electronic version

URL: https://journals.openedition.org/ejas/12212

DOI: $10.4000 /$ ejas. 12212

ISSN: 1991-9336

Publisher

European Association for American Studies

Electronic reference

Richard D. Elliott, "It's Just a Jump to the Right: The Tea Party's Influence on Conservative Discourse", European journal of American studies [Online], 12-2 | 2017, Online since 11 August 2017, connection on 08 July 2021. URL: http://journals.openedition.org/ejas/12212 ; DOI: https://doi.org/10.4000/ejas. 12212

This text was automatically generated on 8 July 2021 .

Creative Commons License 


\title{
It's Just a Jump to the Right: The Tea Party's Influence on Conservative Discourse
}

\author{
Richard D. Elliott
}

\section{Introduction}

But I think the - what the Tea Party movement demonstrates, and I think the, the, the enthusiasm that we're seeing from independents and Republicans, is that if Washington isn't going to change itself, then we're going to change Washington. And I think that's what we're seeing.

Senator John Cornyn, Texas (R), July 18, 2010 (NBC News Staff, 2010)

When Rick Santelli railed against newly inaugurated President Barack Obama's stimulus package as "intrusive government" in February of 2009, he breathed life into America's contemporary populist political movement: the Tea Party (Perlberg 2014). When his message was picked up by local activists across the country (Fang 2013 ; Roesgen 2009), this amorphous coalition of grassroots activists, conservative politicians, and disaffected voters began to grow in political power and eventually ascended to national prominence in the 2010 congressional elections. Some of the most well known and influential Tea Partiers elected that year included Senators Marco Rubio, Rand Paul, and Mike Lee (Palin 2013;Peoples and Ohlemacher 2016: Everett and Min Kim 2016). The Tea Party movement is best characterized by its belief in a limited government and dedication to Constitutional originalism (Ribali 2012) along with vehement opposition to immigration (Tea Party Patriots Staff 2016) and the Affordable Care Act (Tea Party.org Staff 2016). The Congressional Liberty Caucus has a mission to "focus on specific issues like economic freedom, individual liberty, and following the Constitution" (National Journal 2014). The Congressional Freedom Caucus was established in 2015 to be a "smaller, more cohesive, more agile, and more active" group of conservatives. Both causes, although not explicitly Tea Party organizations, are affiliated with the Tea Party movement and have similar goals (Eaton 2015). 
2 The Tea Party is not a political party in the same sense as the Republican or Democratic Party, but is instead a loose movement of grassroots activists, concerned citizens, and donors who intend to inspire change by working within the Republican Party rather than by forming a new political party. While technically not aligned with either major political party, every member of the Tea Party Caucus, Liberty Caucus, and Freedom Caucus has been a Republican (Bachmann 2012), while all 138 candidates with significant Tea Party support in 2010 ran as Republicans (Zernike 2010).

3 In a 2012 poll, CBS News' Brian Montopoli found that 54 percent of Tea Party supporters are Republicans, 41 percent are Independents, and five percent are Democrats; the one tie that binds them is frustration with, and hostility towards, the federal government. Fifty-three percent of respondents described themselves as "angry" with the way things are going in Washington, 88 percent disapproved of President Obama's performance, and 92 percent believed that America was "on the wrong track" (Montopoli 2010).

While the Tea Party is a powerful new force on the American political scene, it is difficult to explain exactly what its positions are, who comprises its membership, or even if it has a true leader, given its emphasis on localized leadership and political activity. When a 2010 Washington Post poll asked 647 Tea Party activists which national figure they believed represented their movement, 34 percent said "no one," 14 percent said 2008 Vice Presidential candidate Sarah Palin, seven percent said nationallysyndicated conservative radio host Glenn Beck, and only four percent said Tea Party Caucus founder Michele Bachmann (Gardner 2010).

5 Professor Leigh Bradberry of California State University at Northridge and Gary Jacobson of the University of California at San Diego have investigated how attitudes toward the Tea Party shaped voting behavior in the 2012 presidential and congressional elections. They believe that the extreme political polarization of 2012 was because the Tea Party is particularly active and vocal in its disagreement with President Obama and the congressional Democrats on a myriad of issues. They also argue that the attitude of "compromise is weakness" promotes ideological purity within the Tea Party, as politicians fear being "Cantor'd"-being ousted in the primary election by more conservative politicians. Bradberry and Jacobson concluded that Tea Party tensions would continue to flare if the winner of the 2016 presidential race was a Democrat, a prediction that will remain untested. (Bradberry and Jacobson 2013).

6 Prior to the rise of the Tea Party, Senator John McCain was elected the 2008 Republican presidential nominee. However, his stance on immigration prevented him from exciting the conservative base (Lizza 2007). So-called "Tancredoism", named after staunch anti-immigration politician and 2008 Republican presidential candidate Tom Tancredo, arose as a result of both weak Republican leadership in the aftermath of George W. Bush's presidency and strong anti-immigrant fervor among the Republican base (Lizza 2007). Mitt Romney, widely considered a moderate during his 2012 run (Dovere 2012), succumbed to Tancredoism and became so staunchly opposed to illegal immigration that he proposed a fence for the United States' border with Mexico. Romney tellingly selected Maricopa County, Arizona's Republican Sheriff Joe Arpaio, an outspoken opponent of illegal immigration (Bogado 2009), as the chair of his Arizona campaign organization in 2012 (Bonisteel 2007). 
7 Donald Trump's successful 2016 campaign, primarily based on the strength of his antiimmigrant and xenophobic rhetoric, should bring attention to how and why such harmful discourse has become normalized by a mainstream political party.

\section{Literature Review}

Philosophers and authors from Plato to Orwell have feared the power of language to exercise influence over the populace (Chilton and Schäffner 2002). Linguistics expert Paul Chilton argues that discourse is essential to politics, as communication and persuasion are vital parts of public debate. He also notes that politics is predominantly conducted in language and that the words that politicians, commentators, and even parents at dinner tables use have a tangible impact on the political process (Chilton 2004). In Politics as Text and Talk, Chilton also notes that language signifies the "in" and "out" groups of society; politics is very much based on these groups and their perceived values. He argues that the development of human communication was a result of cooperative strategies, as opposed to the Machiavellian tendencies of rulers in their earliest days. As political scientist Murray Edelman has stated, "language is not simply an instrument for describing events but is itself a part of events" and, following this definition, the language used to describe political events can influence political perceptions (Edelman quoted by Geis 1987). Joseph furthers this argument by stating that all language is inherently political by virtue of having the potential to shape power relations. (Joseph 2006). In Talking Power, Robin Lakoff argues that the most powerful members of society are deemed more credible and thus, their language has more impact on the population at large. This belief that power translates to legitimacy means that micropolitics, the development and use of strategies that create and enhance power differences amongst individuals, is consequential and impactful: "If politicians say it, it becomes reality" (Lakoff 1990).

9 A number of scholars have investigated the differences in discourse and narrative construction between mainstream Republicans and Tea Partiers. Benjamin Schrader (2011) argues that the discourse of the Tea Party promotes structural violence, as its ideology is so individualistic. He also explores the ties between race and Tea Party discourse and how the movement promotes hyper-masculinity. A study examining the remaking of Republican conservatism into Tea Party ideology explains that the Tea Party's opposition to the federal government is based on the idea that "handouts" are going to "undeserving groups," a perception fueled by racial, ethnic, and gender stereotypes (Williamson, Skocpol, and Coggin 2011). In The Dynamics of Political Discourse, Fetzer, Weizman, and Berlin analyze public debates between Tea Partiers, Democrats, and independent candidates. The analysis of the three-way debates in Minnesota and Florida in 2010 demonstrates the contributions to public discourse of self-described Tea Partiers and how their ideological views differ from those of either Democrats or establishment Republicans (Fetzer, Weizman and Berlin 2015). Colorado State University's Alex Coughlin pointed out the differences in narrative style, the painting of allies and enemies, and perspective between the New York Times and Washington Post, two left-leaning news outlets, and teapartypatriots.org and teaparty.org, the Internet heart of the Tea Party movement (Coughlin 2012). He also compares the rhetoric of the Tea Party to past populist movements and concludes that the Tea Party employs methods similar to past conservative populist movements, particularly the 
theme of ordinary folks opposing "out-of-touch" Washington politicians. Author Clarke Rountree argues that Tea Party rhetoric can be explained by three particular characteristics: evangelical fervor, oppositional stances, and anti-government policies. In particular, that evangelical fervor "bled over" into their political discourse and led to a stark increase in filibusters (Rountree 2013). To a degree, this increase in filibusters contributed to the rise of Tea Party culture by normalizing the rhetoric and tactics they rely upon. Rountree describes this as "my way or the highway" governance. In Change They Can't Believe In, professors Christopher Parker of the University of Washington and Matt Barreto of UCLA analyze how discourse differs between Tea Party elements and members of the mainstream Republican Party. For instance, they speak of the paranoia and conspiratorial nature of Tea Party discourse, which the authors assert means that Tea Partiers are not conservatives, but are truly reactionaries (Parker and Barreto 2013). Cleveland State University's Anup Kumar found that the Tea Party appropriated the Obama message of "change" and redefined it to mean strong antagonism to the "old guard" of Washington, namely Barack Obama, Harry Reid, and Nancy Pelosi, but also some prominent Republicans such as Speaker of the House John Boehner, who resigned due to opposition from Tea Partiers in the House of Representatives (Steinhauer 2015). He also argues that right-wing populists have used the tactics of leftwing community organizer Saul Alinsky to spread their message (Kumar 2011).

I utilize the theories of these researchers to better understand and explain the correlation of Tea Party-supported politicians' rhetoric and mainstream conservative discourse after their ascendance in the 2010 congressional election. Applying Chilton's theory that "talk matters," I note specific changes in rhetorical style and language that were first employed by Tea Party-supported politicians after the 2010 congressional election and more recently used to great effect by Donald Trump, the 2016 Republican nominee and current President.

\section{Methodology}

In this study, I perform rhetorical analysis of speeches to understand how members of the Tea Party Caucus used language to frame political issues after their ascendance in the 2010 congressional elections and how their rhetoric is reflected in mainstream conservative political discourse. The study takes a cultural/linguistic approach, looking at changes in the frequency of fear-inducing language, political myths, racial appeals, conspiratorial accusations, and personal insults.

This study compares the speeches of the most mainstream of Republicans, the party nominees, analyzing speeches made prior to the Republican National Conventions in 2008, 2012, and 2016. To control as many variables as possible, I chose the same five types of speeches for John McCain, Mitt Romney, and Donald Trump: the campaign announcement speech, a foreign policy speech, an immigration speech, a speech to the American Israel Public Affairs Committee (AIPAC) Conference, and the speech after becoming the presumptive nominee. The speeches by the five Tea Partiers after the 2010 congressional elections were each picked because they represented large events: four of the five were speeches at major conservative conventions and the other was Mike Lee's response to the 2014 State of the Union Address.

In theory, speeches by presidential candidates should be more moderate as they are intended to appeal to a wider swath of Americans, thus providing a more moderate 
estimate of the extent of harmful discourse than speeches by members of Congress, which can be tailor-made for hyperpartisan constituencies and special interest groups (Hirano et al 2010). This study tested the theory that the exposure of Americans to Tea Party discourse radicalized American political discourse and allowed extreme discourse to be utilized to great political effect; a theory I believe was supported by Donald Trump's victory in the general election. In short, I believe that the Tea Party served as stalking horses for Trump's rhetoric.

To establish a baseline and identify the boundaries of mainstream conservative political discourse, I first examined the campaign announcement speech, a foreign policy speech, a speech on immigration, a speech to AIPAC, and the presumptive nominee speech from John McCain during his 2008 campaign. Next, I analyzed the language and rhetorical style of politicians who were supported by the Tea Party movement during the 2010 congressional elections, specifically looking for the number of instances of the particular rhetorical strategies I explain below. Then, I analyzed the campaign announcement speech, a foreign policy speech, a speech on immigration, a speech in Jerusalem, and the presumptive nominee speech for Mitt Romney during his 2012 campaign. Finally, I analyzed Donald Trump's campaign announcement speech, a foreign policy speech, a speech on immigration, a speech to AIPAC, and his presumptive nominee speech during his 2016 campaign. Then, I noted the differences in usage of these rhetorical strategies between McCain's, Romney's, and Trump's speeches to chart the evolution of conservative discourse between 2008 and 2016, before examining the similarities in these same rhetorical strategies between Donald Trump and that of Tea Party-supported politicians in the 2010 congressional race to see how the rhetoric of Tea Party-supported politicians fits within the trajectory of mainstream conservative political discourse. Specifically, I looked for divisive discourse that arouses fear in the general population, leads to the excluding and isolating of certain groups, introduces misinformation to the political conversation, and otherwise poisons the political well. This test for a corollary effect between the rise of the Tea Party and the rhetorical strategies they embraced, along with the normalization of their discourse, rather than testing for cause and effect.

To better explore this discourse, I used analytical categories from several sources. The idea of exploiting myths as a political tactic is referenced in The Politics of Language. Political scientist Murray Edelman identified three types of political myths: the "Conspiratorial Enemy," the "Valiant Leader," and "United We Stand." I chose to study this rhetorical strategy because of a correlation between voters with authoritarian views and support for Donald Trump, whereas this was not the case for McCain or Romney voters (Weber, Frederico, \& Feldman 2017).

16 The "Conspiratorial Enemy" refers to the myth of a hostile out-group, which is perceived as different, homogenous, highly potent, or omnipotent and is supposedly conspiring to harm the designated in-group. An example would be Donald Trump saying,

How does this kind of immigration make our life better? How does this kind of immigration make our country better? Why does Hillary Clinton want to bring people here-in vast numbers-who reject our values? Immigration is a privilege, and we should not let anyone into this country who doesn't support our communities - all of our communities (Trump 2016).

17 The "Valiant Leader" myth ascribes to the view that the political leader is benevolent and effective in saving people from danger and also that the leader exhibits the 
qualities of courage and aggressiveness, as well as the ability to cope. An example would be Donald Trump saying,

We need somebody that can take the brand of the United States and make it great again. It's not great again. We need- we need somebody- we need somebody that literally will take this country and make it great again. We can do that (Trump 2016).

"United We Stand" statements support the belief that a group-be it a nation, state, or party-can achieve victory over its enemies if it will only work, sacrifice, and obey its leaders. An example would be Donald Trump saying,

We need somebody that can take the brand of the United States and make it great again. It's not great again. We need- we need somebody- we need somebody that literally will take this country and make it great again. We can do that (Trump 2016).

In Clark Rountree's Venomous Speech, editor Rebecca Cournalia delineates the "politics of fear," with specific examples using fear regarding jobs (e.g., "taxes kill," "regulations kill"). According to Pew, $40 \%$ of Americans and $58 \%$ of Republicans believed there was a high risk of a terrorist attack occurring within our country; the usage of fear-inducing language is to cater to this base (Pew 2016). An example would be John McCain saying,

We are fighting a war in two countries and we're in a global struggle with violent extremists who despise us, our values, and modernity itself. (McCain 2008).

Professor Ian Haney-Lopez's book Dog Whistle Politics explains how dog-whistle rhetoric, language holding a dual meaning for a targeted group, reinvented racist appeals to white Americans. While the language might be viewed as neutral to casual observers, it actually carries racist undertones to the targeted audience. The idea of using subtle, implicit racism to attract white voters while having plausibile deniability to charges of racism is also discussed in Tali Mendelberg's The Race Card: Campaign Strategy, Implicit Messages, and the Norm of Equality. However, the success of Trump's campaign shakes her theory that dog-whistle rhetoric loses its appeal when the content is exposed, mostly because Trump's rhetoric is more klaxon siren than dog whistle. Donald Trump demonstrated this when he said,

When Mexico sends its people, they're not sending their best. They're not sending you. They're not sending you. They're sending people that have lots of problems, and they're bringing those problems with us. They're bringing drugs. They're bringing crime. They're rapists. And some, I assume, are good people. But I speak to border guards and they tell us what we're getting. And it only makes common sense. It only makes common sense. They're sending us not the right people (Trump 2015).

In Change They Can't Believe In, political scientists Christopher Parker and Matt Barreto noted the "conspiratorial nature" of Tea Party discourse, which I attach to the spreading of misinformation and references to conspiracy theories. In particular, statements regarded as untrue and carrying the labels of "Mostly False," "False," and "Pants on Fire" by Politifact on their truth scale or otherwise denoted as untrue by major news organizations meet this criteria. With so many Americans losing trust in mass media and believing that the news has partisan bias, I believed this was an important rhetorical category (Swift 2016). An example would be Sarah Palin saying the following statement, which was denoted as "False" by Politifact.

See, I tried to look into that transparency thing, but Joe's meetings with the transparency and accountability board -- it was closed to the public. Yeah, they held the transparency meeting behind closed doors. (Palin 2010). 
22 I have also included the category of personal insults, such as calling national leaders "stupid" or "out of touch" because Donald Trump was branded as a bully and it has been theorized that his constant use of insults led to increases in bullying over the past year by the Southern Poverty Law Center (Costello 2016).

23 I then coded each speech for instances of harmful discourse in these categories Table 1 shows the results and allows comparison of the number of instances of harmful discourse over time. Table 2 shows the number of instances across each category for McCain, Palin, the Tea Party-affiliated politicians, and Trump individually to show the changes over time.

\section{Research Findings}

Table 1: Cumulative Harmful Discourse over Time

\begin{tabular}{|c|c|c|c|c|}
\hline 2008 McCain & $\begin{array}{l}\text { Transition } \\
\text { Period } \\
(2008-2010)\end{array}$ & $\begin{array}{ll}\text { Tea } & \text { Party } \\
\text { Speeches } & \\
\text { post-2010 } & \end{array}$ & 2012 Romney & 2016 Trump \\
\hline $\begin{array}{l}\text { McCain's Campaign } \\
\text { Announcement } \\
\text { Speech } \\
\text { April 25, } 2007 \\
12 \text { instances }\end{array}$ & $\begin{array}{l}\text { Sarah Palin's } \\
\text { Speech at the } \\
\text { Republican } \\
\text { National } \\
\text { Conference } \\
\text { September 3, } 2008 \\
37 \text { instances }\end{array}$ & $\begin{array}{l}\text { Michele } \\
\text { Bachmann's } \\
\text { Speech at the } \\
\text { Values Voter } \\
\text { Summit } \\
\text { September 14, } 2012 \\
54 \text { instances }\end{array}$ & $\begin{array}{l}\text { Remarks } \\
\text { Announcing } \\
\text { Candidacy for } \\
\text { President in } \\
\text { Stratham, New } \\
\text { Hampshire } \\
\text { June 2, 2011 } \\
14 \text { instances }\end{array}$ & $\begin{array}{l}\text { Remarks } \\
\text { Announcing } \\
\text { Candidacy for } \\
\text { President in New } \\
\text { York City } \\
\text { June 16, } 2015 \\
82 \text { instances }\end{array}$ \\
\hline $\begin{array}{l}\text { Address at the } \\
\text { Hoover Institution } \\
\text { on U.S. Foreign } \\
\text { Policy } \\
\text { May 1,2007 } \\
7 \text { instances }\end{array}$ & $\begin{array}{l}\text { Sarah Palin's } \\
\text { Keynote } \\
\text { Speech at the } \\
\text { Inaugural Tea } \\
\text { Party } \\
\text { Convention } \\
\text { February 6, 2010 } \\
54 \text { instances }\end{array}$ & $\begin{array}{l}\text { Marco Rubio's } \\
\text { Remarks at the } \\
\text { Conservative } \\
\text { Political Action } \\
\text { Conference } \\
\text { February 9, } 2012 \\
31 \text { instances }\end{array}$ & $\begin{array}{l}\text { Remarks on U.S. } \\
\text { Foreign Policy } \\
\text { at The Citadel in } \\
\text { Charleston, } \\
\text { South Carolina } \\
\text { October 7, } 2011 \\
17 \text { instances }\end{array}$ & $\begin{array}{l}\text { Donald Trump's } \\
\text { Foreign Policy } \\
\text { Speech } \\
\text { April 27, } 2016 \\
68 \text { instances }\end{array}$ \\
\hline $\begin{array}{l}\text { Remarks to the } \\
\text { National Association } \\
\text { of Latino Elected \& } \\
\text { Appointed officials } \\
\text { in Washington, DC } \\
\text { June } 28,2008 \\
13 \text { instances }\end{array}$ & & $\begin{array}{l}\text { Ted Cruz's } \\
\text { Speech at the } \\
2012 \text { Republican } \\
\text { National } \\
\text { Convention } \\
\text { August 29, } 2012 \\
17 \text { instances }\end{array}$ & $\begin{array}{l}\text { Remarks to } \\
\text { Republican } \\
\text { National } \\
\text { Hispanic } \\
\text { Assembly in } \\
\text { Tampa, Florida } \\
\text { September 2, } 2011 \\
15 \text { instances }\end{array}$ & $\begin{array}{l}\text { Donald J. Trump } \\
\text { Addresses } \\
\text { Terrorism, } \\
\text { Immigration, } \\
\text { and National } \\
\text { Security } \\
\text { June 13, } 2016 \\
69 \text { instances }\end{array}$ \\
\hline
\end{tabular}




\begin{tabular}{|c|c|c|c|}
\hline $\begin{array}{l}\text { Remarks to the } \\
\text { AIPAC Policy } \\
\text { Conference in } \\
\text { Washington, D.c. } \\
\text { June 2, } 2008 \\
13 \text { instances }\end{array}$ & $\begin{array}{l}\text { Mike Lee's } \\
\text { Response to the } \\
2014 \text { State of the } \\
\text { Union Address } \\
\text { January 28, } 2014 \\
12 \text { instances }\end{array}$ & $\begin{array}{l}\text { Remarks to the } \\
\text { Jerusalem } \\
\text { Foundation in } \\
\text { Jerusalem, } \\
\text { Israel } \\
\text { July } 29,2012 \\
11 \text { instances }\end{array}$ & $\begin{array}{l}\text { Remarks at the } \\
\text { AIPAC Policy } \\
\text { Conference in } \\
\text { Washington, DC } \\
\text { March 21, } 2016 \\
69 \text { instances }\end{array}$ \\
\hline $\begin{array}{l}\text { Remarks Claiming } \\
\text { the Republican } \\
\text { Presidential } \\
\text { Nomination } \\
\text { March 4, } 2008 \\
10 \text { instances }\end{array}$ & $\begin{array}{l}\text { Rand Paul's } \\
\text { Remarks at the } \\
2014 \\
\text { Conservative } \\
\text { Political Action } \\
\text { Conference } \\
\text { March 8, } 2014 \\
16 \text { instances }\end{array}$ & $\begin{array}{l}\text { Remarks in St. } \\
\text { Louis, Missouri: } \\
\text { "A Champion } \\
\text { For rree } \\
\text { Enterprise" } \\
\text { June 7, } 2012 \\
17 \text { instances }\end{array}$ & $\begin{array}{l}\text { Remarks } \\
\text { Claiming the } \\
\text { Republican } \\
\text { Presidential } \\
\text { Nomination } \\
\text { May 4, } 2016 \\
30 \text { instances }\end{array}$ \\
\hline
\end{tabular}

After analyzing the speeches, I found significant increases in all categories of harmful discourse after the 2010 congressional elections. Table 2 shows the increased usage of discourse by speaker, while Table 3 shows usage of discourse by speech. Fear-inducing language was used by John McCain, with 22 total instances, but Donald Trump tripled that with a total of 66 instances. Fear-inducing language also increased in usage after 2010 by both Sarah Palin and the Tea Partiers who were analyzed. Political myth usage increased dramatically, with McCain using 20 and Trump using 97. Finally, personal insults multiplied almost six-fold, with McCain using 13 and Trump using 71. The most interesting finding was that McCain had no instances of racial appeals or conspiratorial accusations in my analysis, whereas Donald Trump used these two forms of harmful discourse in 36 instances. Conspiratorial accusations increased to the point that Donald Trump's campaign misstatements were dishonored as Politifact's 2015 "Lie of the Year" (Holan and Qui 2015). Racial appeals were increasingly aimed against Mexican immigrants, Muslims in the United States and abroad, and especially in questioning Barack Obama's racial and national heritage. The "Conspiratorial Enemy" charge was cast increasingly against prominent Democrats, the federal government as a whole, and even moderate Republicans rather than against foreign enemies of the United States such as Al-Qaeda and ISIS. The "Valiant Leader" and "United We Stand" subcategories within political myths also increased markedly.

Table 2: Harmful Discourse Instances Chart

\begin{tabular}{|l|l|l|l|l|l|l|}
\hline Rhetorical Styles & $\begin{array}{l}\text { McCain } \\
2008\end{array}$ & $\begin{array}{l}\text { Sarah } \\
\text { Palin }\end{array}$ & $\begin{array}{l}\text { Post-2010 Tea } \\
\text { Party }\end{array}$ & $\begin{array}{l}\text { Romney } \\
2012\end{array}$ & $\begin{array}{l}\text { Trump } \\
2016\end{array}$ & $\begin{array}{l}\text { Increases from } \\
\text { McCain to Trump }\end{array}$ \\
\hline Fear-Inducing & 22 & 22 & 32 & 21 & 66 & +44 \\
\hline Political Myths & 20 & 34 & 40 & 28 & 97 & +77 \\
\hline Racial Appeals & 0 & 4 & 11 & 9 & 22 & +22 \\
\hline
\end{tabular}




\begin{tabular}{|l|l|l|l|l|l|l|}
\hline $\begin{array}{l}\text { Conspiratorial } \\
\text { Accusations }\end{array}$ & 0 & 1 & 5 & 1 & 14 & +14 \\
\hline Personal Insults & 13 & 30 & 39 & 14 & 71 & +58 \\
\hline Total & 55 & 127 & 127 & 74 & 270 & +215 \\
\hline
\end{tabular}

\section{Discussion}

Since the election of 2008, there has been a stark increase in harmful rhetoric in conservative discourse. This began to appear with the Tea Party and continued to expand with the rise of Donald Trump. As harmful discourse continues to become normalized, it has the potential to become an expectation in our political process. This has extremely dangerous implications for the social climate of our country as the population of the United States becomes more diverse.

The increase in harmful discourse shown by this study suggests that conservative discourse has reached a point where the formerly taboo has become normalized, particularly because Donald Trump's rhetoric was a major factor in his success (Romm 2016). Multiple articles have been written about the rise of Trumpism: politics that relies upon the strength of personality and strongman authoritarianism that is often reflected through the examples of harmful discourse highlighted by this study (Tumulty \& Costa 2016).

The primary limitations of my study were that I was not able to study every speech in any of the "eras of discourse" that I studied. The study did not address failed candidates in 2008, 2012, or 2016, particularly to see if those who used more harmful discourse did better or worse than their contemporaries. The study also did not address shifts in liberal discourse during the same time period to assess changes in mainstream liberal discourse. Another issue is that there is varying scholarly criteria of harmful discourse and I had to narrow it down to five particular categories. This study was conducted before the 2016 general election and does not include speeches from the Republican National Convention nor the post-RNC campaign. Finally, the study is subject to personal biases, as harmful discourse is ultimately up to the person who is reading the speech and a more conservative individual may find less examples.

30 I plan to expand this study by analyzing the same five types of speeches from Mitt Romney in 2012, along with the Republican National Convention's closing speech from McCain, Romney, and Trump respectively. I eventually want this study to feature those six speeches from every Republican nominee from Barry Goldwater in 1964 to the 2020 Republican nominee during the campaigning process for the primary elections. This would allow me to explain the narrative of who the perceived out-groups were within American society as dictated by conservatives, how polarized the parties are, and develop a further understanding of America's changing political landscape over the past 50 years. This study would also allow me to look at how various harmful political narratives (law and order, welfare queens, etc.) correlate with particular political policies. I also plan to expand this study by doing a rhetorical analysis of speech by Democrats between 2008 and 2016 by first studying the same types of speeches by Barack Obama and Hillary Clinton in 2008 and then by Bernie Sanders and Hillary 
Clinton in 2016. Combining this study with one on Democratic rhetoric over the same time period can give an objective view of shifts in rhetoric and seeing who each party perceived as out groups and how each party uses the rhetorical devices that were measured in this study.

\section{Conclusion}

31 I conclude that Tea Party discourse served as a precursor and correlated with the increased usage of harmful discourse by mainstream conservative politicians. This lends further credence to Parker and Barreto's claim that the Tea Party is truly reactionary rather than just ultra-conservative, as it harkens to a non-existent past where taxes were low, the federal government was small, and America's population was much more homogenous. All five of the rhetorical strategies listed (fear-inducing language, political myths, racial appeals, conspiratorial accusations, and personal insults) have been employed in increasing amounts since the rise of the Tea Party to the national stage. That is a problem because this discourse has real-world repercussions and also has the potential to create a snowball effect of worsening discourse.

As former senior policy analyst Jeff Schweitzer wrote for the Huffington Post, the redefinition of truth in far-right circles has essentially crafted two separate political realities: one based in truth and the other based in fiction (Schweitzer 2012). Without political discourse that is based on statistics and objective facts, compromise is essentially impossible. Delegitimizing harmful discourse in politics as a whole is a necessary step to reintroduce truth and civility to our national conversation and close the "truth gap" that Schweitzer addressed.

Furthermore, University of California-Irvine professor Michael Tesler's research since the election of Barack Obama has shown a growing polarization of Americans on racial matters. As denoted in his books Obama's Race: The 2008 Election and The Dream of a PostRacial America and Obama's Most-Racial, he outlined diverging views on issues that relate to race such as the verdict in the Trayvon Martin case grew alongside those that had even a hint of race, such as the perception of Barack Obama's dog and how Oscarworthy 12 Years A Slave was. In fact, he has found that views about race were even more influential in the 2016 election than the racially groundbreaking 2008 election (Tesler 2016). As Jamelle Bouie outlined in Slate, it can lead to "America becoming Mississippi"the nationalization of the Southern Strategy a la Nixon (Bouie 2014). Demographic shifts that are apparent to white Americans, such as the election of Barack Obama, made white Americans more likely to support conservative policies and conservative politicians. This increasing racial polarization is dangerous for American politics as it only further increases tribalism and is a unique threat to the underlying fabric of American politics and America's civil society. As shown by the history of politics in the Deep South, politics that is divided into "us versus them" is dysfunctional, chaotic, and does not work to improve the lives of citizens. Instead, it refocuses politics to protecting the perceived in-groups and vilifying out-groups. Such a political environment makes anger, particularly among white voters, even more politically salient. In Anger and Racial Politics, Antoine Banks of the University of Maryland- College Park specifically pinpoints how anger regarding race is an enhancing factor for white 
voters to oppose programs they believe are for "others", such as affirmative action and health care reform, or to support the Tea Party.

Chart 1: Tracking Racial Resentment \& Support for the Republican Presidential Candidate
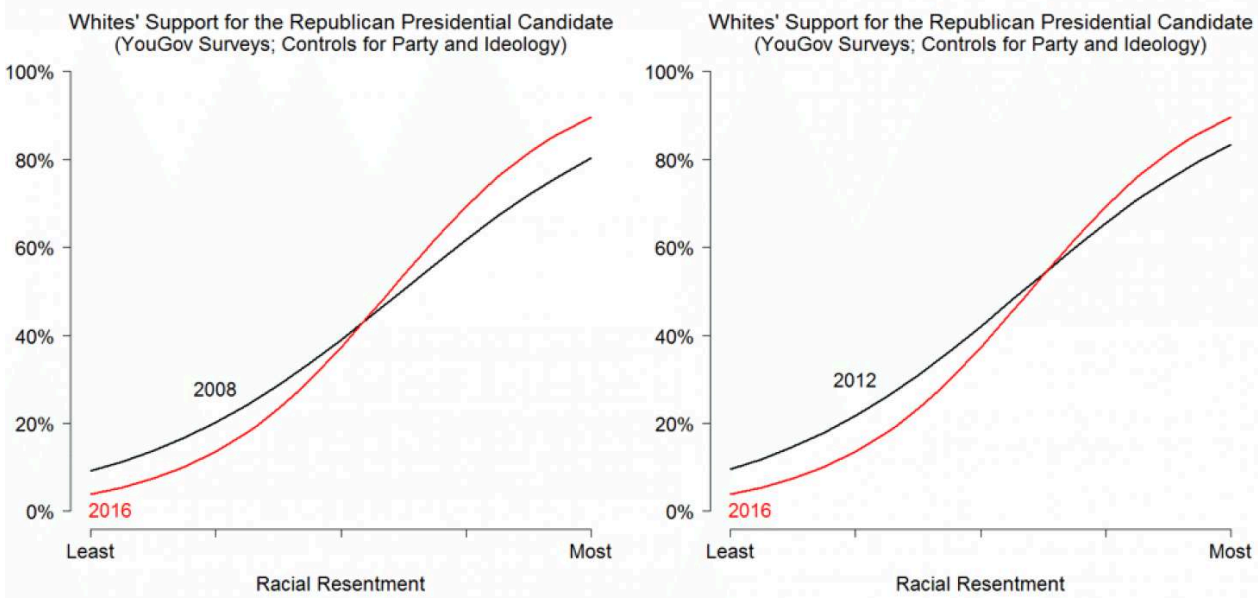

Graph by Michael Tesler. Source: 2008 Cooperative Campaign Analysis Project; 2012 Cooperative Campaign Analysis Project; YouGov/Economist Polls, July 30-August 6, 2016.

Chart 2: Tracking Racial Resentment \& Support for the Republican Presidential Candidate

(con.)
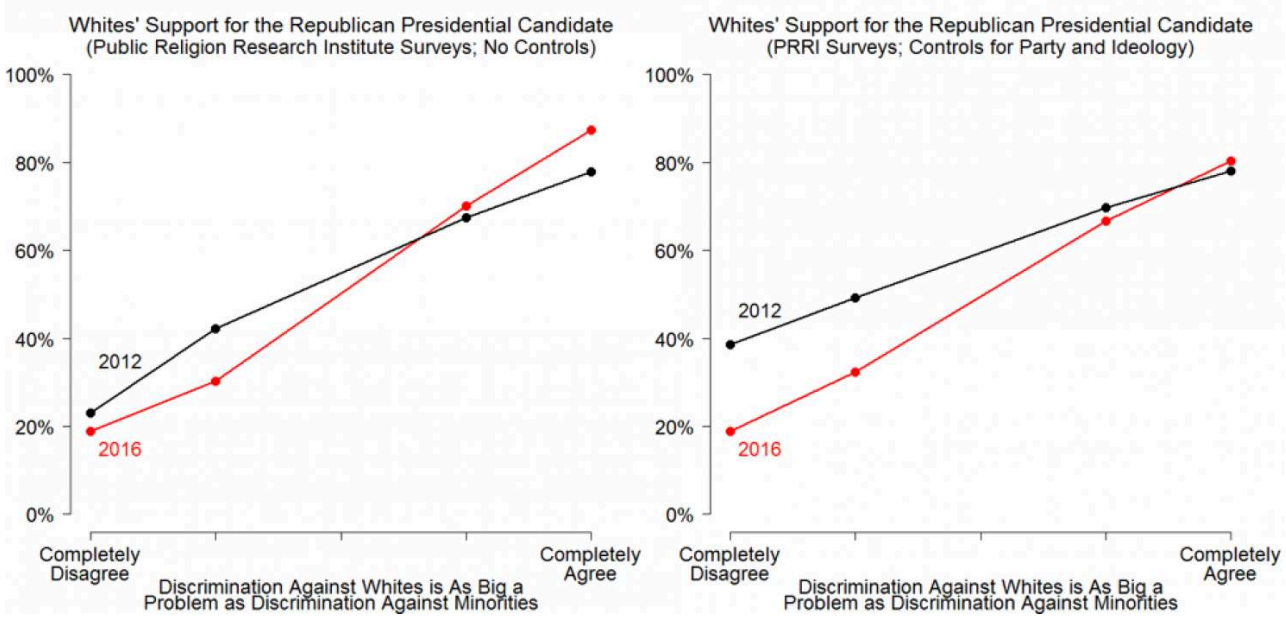

Graph by Michael Tesler; Source: Public Religion Research Institute Surveys, August 2012 and October 2016. Data from August 2012 survey accessed from Roper Center Archives.

\section{BIBLIOGRAPHY}

Bibliography 
Bachmann, Michele. Members of the Tea Party Caucus. Bachmann.house.gov. 2012. https:// web.archive.org/20121212040121/https://teapartycaucus-bachmann.house.gov/membership January $4,2017$.

Banks, Antoine. Anger and Racial Politics: The Emotional Foundation of Racial Attitudes in America. Cambridge Press. 2014.

Bogado, Aura. Arpaio Vs. Immigrants: Those Most Affected Left Out Of Debate. FAIR: Fairness \& Accuracy In Reporting. May 1, 2009. http://www.fair.org/index.php?page=3790 January 4, 2017.

Bonisteel, Sara. Arizona Sheriff Joe Arpaio Tells FOX News Why Mitt Romney Picked Him for Presidential Campaign. Fox News. February 28, 2007. http://www.foxnews.com/story/0,2933,255428,00.html. January 4, 2017.

Bouie, Jamelle. Could America Become Mississippi. Slate. April 9, 2014.

Bradberry, Leigh \& Jacobson, Gary. Does the Tea Party Still Matter?: Tea Party Influence in the 2012 Elections. American Political Science Association. 2013. http://papers.ssrn.com/sol3/papers.cfm? abstract_id=2301066. January 4, 2017.

CBS/AP. “Trump Supporter's Rant at Store Manager Leads to Fundraiser”. Nov, 29, 2016. http:// www.cbsnews.com/news/trump-supporters-rant-at-store-manager-leads-to-fundraiser/. January 4, 2017.

Chilton, P.A. 2003. Analysing Political Discourse: Theory and Practice. London: Taylor and Francis.

Chilton, P.A., and C. Schäffner, eds.2002. Politics as Text and Talk: Analytic Approaches to Political Discourse. City: John Benjamins Publishing

Costello, Marie. B. "The Trump Effect." Southern Poverty Law Center. 2016. https:// www.splcenter.org/20160413/trump-effect-impact-presidential-campaign-our-nations-schools. January 4, 2017.

Coughlin, Alex. The Challenges of Populism: An Analysis of Tea Party Structuring Narratives. Colorado State University. 2011. http://dspace.library.colostate.edu/webclient/DeliveryManager/ digitool_items/csu01_storage/2012/03/21/file_1/126606 January 4, 2017.

Cruz, Ted. Ted Cruz Speech At The Republican National Convention: Full Transcript. 2012.presidentialcandidates.org August 9, 2012. http://2012.presidential-candidates.org/?news=Ted-Cruz-SpeechAt-The-Republican-National-Convention:-Full-Transcript. January 4, 2017.

Dovere, E.I. Mitt Romney's Moderate Muddle. Politico. October 10, 2012. http://www.politico.com/ story/2012/10/mitts-moderate-muddle-082261 January 4, 2017.

Eaton, Sabrina. "It's official: Rep. Jim Jordan now chairs the House Freedom Caucus". Cleveland. February 11, 2015. http://www.cleveland.com/open/index.ssf/2015/02/

its_official_rep_jim_jordan_no.html January 4, 2017.

Eichler, Steve. About Us - Tea Party. Tea Party. 2012. http://www.teaparty.org/about-us/

Everett, Burgess. and Min Kim, Seung. The Freshman With More Senate Sway Than Cruz Or Rubio. Politico. January 9, 2016. http://www.politico.com/story/2016/01/mike-lee-utah-senate-21725. January 4, 2017. 1

Eversley, Melante. "Post-election Spate of Hate Crimes Worse than Post-9/11, Experts Say." USA Today. Gannett Satellite Information Network, 14 Nov. 2016. http://www.usatoday.com/story/ news/2016/11/12/post-election-spate-hate-crimes-worse-than-post-911-experts-say/93681294/. January $4,2017$. 
Fang, L. The Machine: A Field Guide to the Resurgent Right. The New Press. 2013.

Fetzer, A., Weizman, E. \& Berlin, L.N. The Dynamics of Political Discourse: Forms and Functions of Follow-ups. John Benjamins Pub., 2015.

Haney-Lopez, Ian. Dog Whistle Politics: How Coded Racial Appeals Have Reinvented Racism and Wrecked the Middle Class. City: Oxford University Press. February 2014.

Hirano, Shigeo, James M. Snyder Jr., Stephen Daniel Ansolabehere, and John Mark Hansen. 2010. Primary elections and partisan polarization in the U.S. Congress. Quarterly Journal of Political Science 5(2): 169-191. http://nrs.harvard.edu/urn-3:HUL.InstRepos:9949294. January 42017.

Holan, Angie Drobnic \& Qiu, Linda. 2015 Lie of the Year: The Campaign Misstatements of Donald Trump. Politifact. December 21, 2015. http://www.politifact.com/truth-o-meter/article/2015/dec/ 21/2015-lie-year-donald-trump-campaign-misstatements/. January 4, 2017.

Gardner, Amy. Gauging the Scope of the Tea Party Movement in America. The Washington Post. October 24, 2010. http://www.washingtonpost.com/wp-dyn/content/article/2010/10/23/ AR2010102304000.html. January 4, 2017.

Geis, Michael. The Language of Politics. Springer New York. 1987.

Joseph, J.E. Language and Politics. Columbia University Press. June 21, 2006.

Lano, Nico. Trump Supporter Attacks Elderly Gay Man: "My President Says We Can Kill You". Nov. 2016. http://www.advocate.com/politics/2016/11/18/trump-supporter-attacks-elderly-gay-man-mypresident-says-we-can-kill-you. January 4, 2017.

Lakoff, R. Talking Power: The Politics of Language in Our Lives. Basic Books. 1990.

Lee, Mike. Full Text: Sen. Mike Lee's Tea Party Response to Obama's State of the Union Speech. U.S. News. January 28, 2014. http://www.usnews.com/news/articles/2014/01/28/full-text-sen-mike-leestea-party-response-to-obamas-state-of-the-union-speech. January 4, 2017.

Lizza, Ryan. Return of the Nativist. The New Yorker. Conde Nast. December 17, 2007. http:// www.newyorker.com/magazine/2007/12/17/return-of-the-nativist. January 4, 2017.

Kumar, Anup. Tea Party Movement: The Problem of Populism as Discursive Practice. Cleveland State University. April 4, 2011. http://eds.b.ebscohost.com/eds/pdfviewer/pdfviewer? sid=35735fd2-5b97-4514-9daf-47788e7e99f8\%40sessionmgr105\&vid=0\&hid=104. January 4, 2017.

McCain, John. Address at the Hoover Institution on U.S. Foreign Policy. Online by Gerhard Peters \& John T. Woolley. The American Presidency Project. May 1, 2007. http:// www.presidency.ucsb.edu/ws/?pid=77107. January 4, 2017.

McCain, John. Remarks Announcing Candidacy for President in Portsmouth, New Hampshire. Online by Gerhard Peters \& John T. Woolley. The American Presidency Project. April 25, 2007. http:// www.presidency.ucsb.edu/ws/?pid=77126. January 4, 2017.

McCain, John. Remarks Claiming the Republican Presidential Nomination Following the Ohio, Rhode Island, Texas, and Vermont Primaries. Online by Gerhard Peters \& John T. Woolley. The American Presidency Project. March 4, 2008. http://www.presidency.ucsb.edu/ws/?pid=76461. January 4, 2017.

McCain, John. Remarks to the American Israel Public Affairs Committee Policy Conference in Washington, D.C. Online by Gerhard Peters \& John T. Woolley. The American Presidency Project. June 2, 2008. http://www.presidency.ucsb.edu/ws/?pid=77412. January 4, 2017. 
McCain, John. Remarks to the National Association of Latino Elected and Appointed Officials in Washington, DC. Online by Gerhard Peters \& John T. Woolley. The American Presidency Project. June 28, 2008. http://www.presidency.ucsb.edu/ws/?pid=77558. January 4, 2017.

Mendleberg, Tali. The Race Card: Campaign Strategy, Implicit Messages, and the Norm of Equality. Princeton University Press. 2001.

Montopoli, Brian. Tea Party Supporters: Who They Are and What They Believe. CBS News. December 14, 2012. http://www.cbsnews.com/news/tea-party-supporters-who-they-are-and-what-theybelieve/. January 4, 2017.

NationalJournal.com. Conservatives Form Their Own Caucus Because the RSC Isn't 'Hard-Core' Enough. 2015. https://www.nationaljournal.com/s/63577. January 4, 2017.

NBC News Staff. Cornyn: 'Slanderous' to Accuse Tea Party of Racism. NBCNews.com., 18 July 2010. http://www.nbcnews.com/video/meet-the-press/38297939. January 4, 2017.

Palin, Sarah. Palin's Speech at the Republican National Convention. Transcript., September 3, 2008. http://elections.nytimes.com/2008/president/conventions/videos/transcripts/ 20080903_PALIN_SPEECH.html. January 4, 2017.

Palin, Sarah. Rand Paul. TIME Magazine. April 18, 2013. http://time100.time.com/2013/04/18/ time-100/slide/rand-paul/. January 4, 2017.

Palin, Sarah. Tea Party Convention Keynote Speech (Complete Transcript, Audio \& Video). American Rhetoric., February 26, 2010. http://www.americanrhetoric.com/speeches/ sarahpalin2010teapartykeynote.htm. January 4, 2017.

Paul, Rand. CPAC 2014: Rand Paul Speech Full Transcript \& Video - Electing Lovers of Liberty. Maggie's Notebook., March 8, 2014. http://www.maggiesnotebook.com/2014/03/cpac-2014-rand-paulspeech-full-transcript-video-electing-lovers-of-liberty/. January 4, 2017.

Parker, Christopher. and Barreto. Matt. Change They Can't Believe In: The Tea Party and Reactionary Politics in America. Princeton University Press. May 26, 2013.

Peoples, Steve. and Ohlemacher, Stephen. Rubio Not Releasing His Delegates In Bid To Stop Trump. Associated Press. March 29, 2016. http://www.sun-sentinel.com/news/politics/fl-ap-rubiorepublican-convention-20160329-story.html. January 4, 2017.

Perlberg, Steven. Rick Santelli Started The Tea Party With A Rant Exactly 5 Years Ago Today - Here's How He Feels About It Now. Business Insider. Business Insider, Inc. February 19, 2014. http:// www.businessinsider.com/rick-santelli-tea-party-rant-2014-2. January 4, 2017.

Pew. 15 Years After 9/11, a Sharp Partisan Divide on Ability of Terrorists to Strike U.S. Pew Research Center. September 7, 2016.

Ribali, Kristina. First Principles: The Tea Party Focuses GOP Platform on Limited Government. FreedomWorks., August 21 2012. http://www.freedomworks.org/content/first-principles-teaparty-focuses-gop-platform-limited-government. January 4, 2017.

Richert, Catharine. "Palin Claims Biden Held a Transparency Board Meeting behind Closed Doors." Politifact. February 9, 2010. http://www.politifact.com/truth-o-meter/statements/2010/ feb/09/sarah-palin/palin-claims-biden-held-transparency-meeting-behin/.January 4, 2017. Roesgen, Andy. Protestors Gather for Self-Styled Tea Party. myfoxchicago.com. February 27, 2009. http://www.myfoxchicago.com/dpp/news/TeaParty. January 4, 2017. 
Romney, Mitt. Transcript of Mitt Romney's Speech on Donald Trump. The New York Times. The New York Times. March 3, 2016. http://www.nytimes.com/2016/03/04/us/politics/mitt-romneyspeech.html. January 4, 2017.

Rountree, Clarke. and Rebecca. Cournalia, eds. Venomous Speech: Problems With American Political Discourse on the Right and Left, Volume 2. ABC-CLIO. 2013.

Romm, Joe. “Donald Trump May Sound Like A Clown, But He Is A Rhetoric Pro Like Cicero". Mar. 28, 2016. https://thinkprogress.org/donald-trump-may-sound-like-a-clown-but-he- is-a-rhetoricpro-like-cicero-ac40fd1cda79\#.fg1go1ct0. January 4, 2017.

Rubio, Marco. ICYMI: Rubio Speaks At CPAC 2012. U.S. Senator for Florida, Marco Rubio., February 9. 2012. https://www.rubio.senate.gov/public/index.cfm/press-releases?ID=AB463882-0FE4-4CADB191-F8426824A860. January 4, 2017.

Ryan, Josiah. “'This was a whitelash': Van Jones' take on the election results”. Nov.3, 2016. http:// www.cnn.com/2016/11/09/politics/van-jones-results-disappointment-cnntv/. January 4, 2017.

Schrader, B.T.G. The Tea Party: The Discourse of Class, Race, \& Gender/Sexuality. Thesis. Colorado State University, 2011.

Schweitzer, Jeff. Mythical Misinformation: Fighting Apocalyptic Apparitions. The Huffington Post. April 17, 2012. http://www.huffingtonpost.com/jeff-schweitzer/mythical-misinformationf_b_459436.html. January 4, 2017.

Steinhauer, Jennifer, (September 25, 2015). "John Boehner Will Resign From Congress". The New York Times. January 4, 2017.

Swift, Art. Americans' Trust in Mass Media Sinks to New Low

Gallup. September 14, 2016

Tea Party.org Staff, No Obamacare. Tea Party.org. 2016. http://www.teaparty.org/no-obamacare/. January 4, 2017.

Tea Party Patriots Staff. Real Immigration Reform. Tea Party Patriots., 2016. http:// www.teapartypatriots.org/real-immigration-reform/. January 4, 2017.

Tesler, Michael. Obama's Race: The 2008 Election and The Dream of a Post-Racial America. University of Chicago Press. November 15, 2010.

Tesler, Michael. Obama's Most-Racial. University of Chicago Press. 2017.

Tesler, Michael. Views about race mattered more in electing Trump than in electing Obama. Washington Post. November 22, 2016.

Trump, Donald. Donald J. Trump Addresses Terrorism, Immigration, and National Security. donaldjtrump.com. June 13, 2016. https://www.donaldjtrump.com/press-releases/donald-j.trump-addresses-terrorism-immigration-and-national-security. January 4, 2017.

Trump, Donald. Donald Trump Actually Read His Victory Speech From A Teleprompter. Here's The Transcript. Vox.com. June 7, 2016. http://www.vox.com/2016/6/7/11880448/donald-trumpvictory-speech-transcript. January 4, 2017.

Trump, Donald. Remarks Announcing Candidacy for President in New York City. Online by Gerhard Peters \& John T. Woolley. The American Presidency Project. June 16, 2015. http:// www.presidency.ucsb.edu/ws/?pid=110306. January 4, 2017. 
Trump, Donald. Remarks At The AIPAC Policy Conference in Washington, D.C. Online by Gerhard Peters \& John T. Woolley. The American Presidency Project. March 21, 2016. http:// www.presidency.ucsb.edu/ws/?pid=116597. January 4, 2017.

Trump, Donald. Remarks on Foreign Policy at the National Press Club in Washington, DC. Online by Gerhard Peters \& John T. Woolley. The American Presidency Project. April 27, 2016. http:// www.presidency.ucsb.edu/ws/?pid=117813. January 4, 2017.

Tumulty, Karen. \& Costa, Robert. This Is Trumpism: A Personality-fueled Run That Resonates In An Anxious Era. The Washington Post. June 13, 2016. https://www.washingtonpost.com/politics/ after-orlando-trump-blows-past-political-norms/2016/06/13/

f97ef168-317d-11e6-8ff7-7b6c1998b7a0_story.html Jnaury 4, 2017.

Weber, Christopher et al. How authoritarianism is shaping American politics (and it's not just about Trump). New York Times. May 10, 2017.

Williamson, Vanessa, Skocpol, Theda. \& Coggin, John. The Tea Party and the Remaking of Republican Conservatism. Oxford University Press. January 1, 2011. http://scholar.harvard.edu/files/ williamson/files/tea_party_pop.pdf January 4, 2017.

Zernike, Kate. Tea Party Set to Win Enough Races for Wide Influence. The New York Times. October 14, 2010. http://www.nytimes.com/2010/10/15/us/politics/15teaparty.html?_r=1\&hp. January 4, 2017.

\section{ABSTRACTS}

This study analyzes the correlation of rhetoric usage by members of Congress who were supported by the Tea Party political movement with changes in mainstream conservative political discourse. The rhetoric of these politicians after the Tea Party's ascendance in the 2010 congressional elections was compared to the rhetoric used by the 2008, 2012, and 2016 Republican nominees to understand the correlation with other changes in conservative discourse. I studied this discourse shift using speech analysis to code for instances of negative discourse and establish a comparison between these election years while also noting rhetorical shifts evident among mainstream conservative politicians.

\section{INDEX}

Keywords: Tea Party, conservatism, Republican Party 